\title{
9
}

\section{Inequalities of Aspiration: Class, Cargo and the Moral Economy of Development in Papua New Guinea}

\author{
John Cox
}

\section{Introduction}

This chapter explores the contours of contemporary Papua New Guinean (PNG) ideologies of nation-making and development and examines how narratives of development are constructed by the nation's urban middle class, based on aspirations for their own personal advancement and the development of the nation as a whole. These aspirations are changing relationships between urban professionals and their rural kin; remittance payments, for example, are being reframed in a developmental idiom as 'projects' or 'business' (see also Filer, this volume). However, the changes are not simply transactional; at a more affective register, I argue that middle-class Papua New Guineans are demonstrating something like the 'sentimental cosmopolitanism' identified by Black (2009) in the connections between donors and recipients of the KIVA Microfinance program.

These developmental aspirations and reworking of relationships are founded on a moral valuation of particular classes of people, usually glossed as 'elites' and 'grassroots' (Cox, 2013). As Gregory and Altman 
argued in their preface to a recent volume that explored theories of domestic moral economy, 'a study of values, then, must examine the social relations of the valuers and note the differences between points of view and moral environments' (Gregory \& Altman, 2018, p. xviii). This chapter analyses a distinctive middle-class PNG moral economy, one that is profoundly shaped by discourses of development and citizenship (see also the differently situated but complementary moral economy analyses by Bainton; Filer; Gewertz \& Errington; Zimmer-Tamakoshi, this volume). It seeks to understand how PNG professionals come to view their rural kin as having a 'cargo cult mentality' (bearing in mind that the grassroots also demonstrate a moral critique of this hierarchy) (Gewertz \& Errington, this volume; Golub, 2014, p. 172; Smith, 2018, p. 46ff.).

In popular PNG articulations of ideal relations between classes, middle-class 'elites' are imagined as mobile, both spatially and temporally, because their lives move through various experiences and usually along a professional career path that accumulates financial, social and cultural capital. The grassroots, by comparison, are denied these same mobilities and are imagined, if in their rightful place, as static — rooted in traditional subsistence village life, where they provide for all of their own needs as an 'innocent population' (Golub, 2014, p. 160ff.). When the grassroots display aspirations that imply mobility beyond their prescribed place, their desires are likely to be delegitimised by accusations of exhibiting a 'cargo cult mentality'. As Golub put it, 'grassroots who ... seek development, wealth and modernity are excoriated by urbanites for betraying the nation's deepest values' (Golub, 2014, p. 162).

The term 'cargo cult' was originally coined to describe Melanesian social movements that wrestled with the meaning of colonial rule, and the attendant inequalities of wealth and racial subordination, in a search for 'moral equivalence' (Burridge, 1960). Many cargo cults flourished after World War II, when the Australian colonial order had been disrupted. Some were millennial movements that sought to change the situation through spiritual power, emphasising a fusion of traditional Melanesian mythology and Christianity (Bainton, 2008; Lattas, 2007; Lawrence, 1964; Lindstrom, 1993; Macintyre, 2013). Others, such as Maasina Rule in Solomon Islands, were more secular organisations that challenged colonial power through activism and negotiation with British authorities (Akin, 2013). 
Today, a number of these movements persist. Some have even taken ownership of the term cargo cult, but in common parlance, the 'cargo cult mentality' is a pejorative term. As I demonstrate below, with the case of the PNG community development worker Andrew, it is frequently used to disparage the expectation of rural people regarding access to wealth and development by implying that they expect material rewards to appear as if by magic. Gamblers are sometimes referred to in this way as people who expect to gain money without work (Macintyre, 2011). A further implication is that the grassroots are lazy and, rather than working for their own living, prefer dependency on their relatives, the state or aid programs. Cargo cult mentality is now a synonym for 'handout mentality'; the use of this phrase marks class privilege.

These disparities of power notwithstanding, middle-class aspirations are not purely selfish. Many urban professionals do maintain close relationships with the grassroots and aspire to better the lot of their rural kinsfolk. Indeed, the 'moral career' of most professionals in PNG includes ideals of scaling a career ladder and accumulating sufficient resources to be able to 'give back' to village relatives. As Debra McDougall shows in her chapter in this volume, this sometimes results in sustained and creative projects that have considerable legitimacy and impact on the ground. More often, however, townsfolk simply imagine themselves returning to 'the village' in their retirement and those who have not made ongoing contributions to the life of the village community may find themselves less welcome than they anticipated (Dalsgaard, 2013; Macintyre, 2011; Rasmussen, 2015; Zimmer-Tamakoshi, 1997).

Relationships between town and village are increasingly being articulated in the idiom of development. The grassroots are becoming recipients of the generosity of their middle-class relatives, who sponsor small-scale 'projects' or business activities that are within the financial means of the donor (Rasmussen, 2015). Sometimes, they are even able to attract development projects funded by external aid agencies (e.g. Suti, Hoatson, Tafunai \& Cox, 2020). These practices echo Melanesian systems of political patronage in which any residual visions of equitable and reliable state-run services are displaced by personalised disbursement of goods (Cox, 2009). The dependency implied is disparaged as 'cargo cult mentality', but the grassroots are also disciplined into accepting their clientelist position, while their aspirations for basic health and education services are ignored. 


\section{Class Distinction and Development in Papua New Guinea}

Alongside Martha Macintyre, several of the other contributors to this volume have made significant contributions to scholarly understandings of how class distinction in PNG is being shaped through moral evaluations of people that are based in ideas of modern development. Deborah Gewertz and Fred Errington, in a 1998 article titled 'Sleights of hand and the construction of desire in a Papua New Guinea modernity' (see also Gewertz \& Errington, 1999), documented a now-familiar process of the production of narratives of blame to account for economic inequality in PNG. These insights into class, development and inequality have also been advanced by Nick Bainton's work on the social effects of mining in Lihir and Paige West's studies of conservation projects in the PNG highlands (see below).

Let me begin with the work of Gewertz and Errington-they tell the story of a microenterprise organisation operating in Wewak, the provincial capital of East Sepik Province. The organisation was founded to provide assistance and relief to women who produce handicrafts but struggle to sell them at a profit. This organisation did so through training programs that instilled entrepreneurial disciplines and aspirations, such as participating in a trade fair in Jayapura, across the border in Indonesia. Gewertz and Errington viewed these ideologies of business as justifications of personal accumulation in a society where this invites jealousy and where such accumulation is regarded as immoral. However, as their analysis proceeded, it became apparent that these new entrepreneurial disciplines of the self and other features of the training did not deliver success in business. If anything, the programs set women up to fail and to accumulate debts that had not burdened them previously. But, another outcome was a new moralising of money and business; women who had not succeeded in their business ventures could now be judged-by others and also by themselves - not to have been working hard enough and, therefore, as undeserving, poor and failed citizens. Gewertz and Errington located this within the nascent PNG class system:

These processes, reflecting middle-class expectations, were based on a modernist claim that almost anyone could gain access to a certain quality of life. Almost everyone had the potential opportunity and capacity, indeed the right and virtual obligation, to work and save in order to consume self-evidently desirable goods and services. 
Correspondingly, according to this formulation, those unable or unwilling to accumulate and therefore acquire these goods and services would have primarily themselves to blame. Any ensuing and persistent inequality would thus be understood as less the product of unfair exclusion or repudiation of kin obligations than of personal failure to fulfil reasonable expectations. (Gewertz \& Errington, 1998, p. 346)

This observation of the dynamics of self-blame and its alienating effects mirrors anthropological analysis of similar phenomena in different contexts and times, such as Cahn's $(2006,2008)$ work on multi-level marketing in Mexico; the critical feminist literature on microfinance, such as Karim's 2011 study of Bangladesh; Schuster's 2015 work in Paraguay or Schiffhauer's (2018) study of pyramid schemes in Siberia. Neoliberal ideologies of individual opportunity have been highly successful in obscuring the structural factors that entrench inequality everywhere. Moreover, in an era of the retreat of social protections provided by the welfare state-or, in the case of PNG and similar developing countries, the failure of the postcolonial state to build an effective welfare systemthe financialisation of people's 'social collateral' (Schuster, 2015) undermines existing social safety nets that sustain the poor. Indeed, in the Western Pacific, the so-called 'wantok system' is a keystone of a national ideology of the resilience of kin-based social protection. The grassroots are imagined as existing in a realm of subsistence affluence and traditional social harmony, in which all their needs are met without cash nor the state; therefore, this ideology justifies both middle-class accumulation and inadequate state services (Cox, 2016, 2018; Cox \& Phillips, 2015; Schram, 2015; cf. Rooney, 2019).

In PNG and other countries in the Global South, these ideologies are deeply embedded in private sector developments, such as large-scale mines or the massive Papua New Guinea Liquefied Natural Gas Project (see Bainton; Main, this volume). Bainton has written of the long-running 'Personal Viability' (more commonly known as 'PV') program: a private company, led by a well-known PNG businessman of Chinese descent, who has developed his advice on how to prosper in business and life into a very popular personal development course (Bainton, 2010, 2011; Bainton \& Cox, 2009). PV is highly moralistic in tone. It begins by asking its participants the pointed question, 'are you viable?' (Bainton, 2011), by way of introducing a personal stocktake of income and expenditure that 
leads people on a path of accumulation and of exactly the kind of moral justification of the refusal of kinship obligations envisaged by Gewertz and Errington.

In Lihir, PV was adopted by elite local leaders as the foundation for their long-term development manifesto that mapped out a future 'road' to a prosperous and 'viable' society that would maximise the benefits of mining and reduce the so-called 'resource dependency syndrome'. Their commitment to the PV program was a contemporary 'rational' response to an actually-existing cargo cult that had flourished in Lihir in the pre-mining era, which cultivated visions of 'instant wealth' (Macintyre, 2013) and the transformation of Lihirian villages into a metropolitan city (Bainton, 2008). An older generation of Lihirians has interpreted the mine as the (partial) fulfilment of these earlier prophecies, which partly explains the heightened expectation for the company to 'deliver the goods'. But, if the ideology of $\mathrm{PV}$ encourages grassroots business activities and promises to unleash an entrepreneurial spirit that will free people from their reliance upon the company, it also mystifies the inequalities in how the financial benefits of the mine are distributed and provides a moral justification for the accumulative practices of Lihirian elites (Bainton, 2010).

Similar practices and ideologies are also found within government (sometimes exactly: in 2007, I observed notices advertising PV training for high-level public servants in Honiara, the capital of Solomon Islands) and in bilateral development programs sponsored by donor partners, such as Australia (where the official aid program is intensifying its commitment to business and entrepreneurship). They also characterise many of the community programs run by international non-governmental organisations (NGOs), including conservation initiatives (West \& Aini, this volume). At local and national scales, in the private and not-for-profit sectors, development is increasingly articulated as a modernising and moralising project of capital accumulation by individuals.

In her 2001 article, 'Environmental NGOs and the nature of ethnographic inquiry', Paige West provided a compelling analysis of how these classbased discourses of development disparage and infantilise the rural poor (see also West, 2006). West described the essentialist expectations of Western conservationists who were disappointed with the failure of Gimi people to conform to their fantasies of what indigenous rainforest people should be. By assuming Gimi to be culturally inauthentic, conservationists legitimised their own ways of seeing land and the environment and 
rendered the landowners and their (misunderstood) foraging and gardening practices as 'threats to biodiversity'. West has continued to document these processes of dispossession in a now substantial body of work (e.g. West, 2016), but here I wish to focus on her critique of the paternalistic dispositions of middle-class Papua New Guineans working for the international NGO Conservation International, particularly their use of the term 'cargo cult mentality'.

West described an incident where villagers, unsatisfied with the minimal benefits of their participation in the conservation scheme, had dared to confront NGO workers with a list of their unmet needs. These included medicine, a water supply, unspecified consumer goods and food for children (West, 2001, p. 64). None of these seems unreasonable or overly ambitious - they represent aspirations for basic needs that many middleclass Papua New Guineans simply assume as an entitlement. However, the response from the NGO worker was highly aggressive and condescending, accusing the villagers of having a 'cargo cult mentality' — of not wanting to work for their own benefit, but expecting material goods and wealth to 'magically' appear. As West argued, 'dismissing the development needs of Maimafu village by referring to local desires as a "cargo" mentality is an exercise in power' (West, 2001, p. 65).

Accusations of 'cargo cult mentality' are exercises in class-based powerdiscursive exercises that imagine the urban middle class as hard-working modern citizens and 'grassroots' villagers as primitive, superstitious and backward (Golub, 2014, pp. 171-177). These discourses occupy a prominent place in public discussions of development and fears of aid dependency, in addition to politics. I have previously argued (Cox, 2009) that cargo cult accusations in Solomon Islands are used to discipline villagers who ask for the wrong kinds of benefits from NGOs, as is also clearly demonstrated by West's example. However, this experience also points to a practice where villagers learn to secondguess these self-appointed catalysts of development; therefore, it reflects the same kinds of relationships that characterise political patronage in Melanesia (Cox, 2009). These dynamics closely parallel the racialised and gendered hierarchies that Papua New Guineans, especially women, experience in working with Australian and other international aid programs (Spark, 2020). 
Politicians establish and retain their influence through distributions of favours, goods and money, a practice that has been deeply entrenched by increases to constituency development funds (public money that can be disbursed at an individual member of parliament's discretion) in both Solomon Islands and PNG (Cox, 2009; Wood, 2019). Although these relationships are often analysed in terms of reciprocity, in practice, it is the patrons, not the clients, who benefit from these highly extractive patronage systems. Politicians routinely complain that they are not ATMs' (in reference to frequent requests for financial assistance) and label their constituents as having a cargo cult mentality or a 'handout mentality' (Okole, 2003). In common parlance, the two terms have largely merged, but the former emphasises credulous waiting for wealth to appear by supernatural means and the latter laziness and dependency. Thus, in one simple and familiar step, cargo cult discourse legitimises the accumulative practices of 'big shots' (Martin, 2013) and renders the aspirations and demands of their followers immoral, greedy and superstitious or backward. For anthropologists, this step was first taken by colonial administrators who were threatened by indigenous movements that questioned the inequalities of the colonial system (Akin, 2013; Burridge, 1960; Lindstrom, 1993). Therefore, it is disappointing (but not entirely surprising) to observe the long life of this colonial trope now being weaponised by the postcolonial elite and even becoming entrenched as a mainstream theme in nation-making discourses (Cox, 2018, pp. 71ff.; Lattas, 2007, p. 157; Lindstrom, 1993, pp. 15ff.).

\section{Class, Cargo and Money Schemes}

These dynamics played out in a similar way in my research on 'fast money schemes', the epidemic of pyramid schemes that captured the imagination of PNG's middle class in the late 1990s and that has never really subsided (Cox, 2019). As Verdery (1995) argued, pyramid schemes provide an invaluable window into social transformations and class-based aspirations. Fast money schemes remain a part of 'popular economies' (Krige, 2012) in PNG. Some, such as the Bougainvillean fraud U-Vistract and the Papalain scam from Morobe Province, have had a remarkable 'long tail' and, more than 20 years later, continue to operate, albeit largely within their core regional constituencies, rather than among the national middle-class (Cox, 2018, 2019). In the heyday of the fast money schemes, the scale of participation and money contributed was driven by middle-class investors 
who were drawn not only by the promise of 100 per cent monthly returns on their money, but also by a heady cocktail of (unfulfilled) promises: being able to realise national development, embodying entrepreneurial dispositions, finding favour with God and bridging what Burridge called the 'moral equivalence' with the cosmopolitan world of the global middle-class, imagined largely through the lens of white Australia (Cox, 2015).

In the years following the crash of the fast money schemes in 1999, a cargo cult narrative emerged that was explicitly structured around class. Those who had lost their money in the schemes were imagined to be acting according to a cargo cult mentality-unthinking, credulous and having a magical view of the production of money, consumer goods and wealth that was divorced from the realities of labour or the discipline of saving. The following editorial in The National provides a typical example:

Why do people 'invest' in these schemes? At first, when U-Vistract hit the headlines, it appeared that many initial investors had indeed reaped huge returns on small investments. That is precisely the way in which these schemes operate. The first investors will always receive large dividends-but, as the scheme continues, and more investors take part, the returns diminish until no returns are paid. That is why these schemes are referred to internationally and in PNG as 'pyramid schemes'; the pyramid shape reflects the diminishing returns to those who have entrusted their money to these frauds. Some of the more sophisticated investors back in those days began to realise the truth of the situation. They and other educated potential investors put their money elsewhere.

Today, and for some years past, these cruel and unlawful schemes target the simplest of our people, very often squatters and simple village people. These people believe what they are so enthusiastically and persuasively told. And, of course, the golden promises have been added to by dark suggestions that the established banks and the government have some vested interest in blocking the people from the rightful gains such organisations could provide. We still have not succeeded in persuading these thousands of our countrymen and women that such fast money is nothing but a pipe dream, more allied to the cargo cults of old, than to modern schemes designed to improve people's incomes. The old adage 'nothing for nothing, and precious little for sixpence' is accurate when describing the whole field of making money. Broadly speaking, there is only one sure way of making money, and that is through hard work. That is not, of course, a palatable answer for thousands of our people living at or beneath the poverty line. 
Anything that can promise some relief from their present situation is bound to be seized upon with enthusiasm. It is not until they learn the hard way, by not only not making profits, but by losing what they have been able to invest, that they come to realise the nature of these schemes. ('Modern Shylocks', 2005)

This account draws on classic 'cargoist' (Lindstrom, 1993) themesit articulates a popular ideology of class-based inequalities of aspiration. The lower classes of the rural poor and urban squatters are represented as poor, simple, gullible and not understanding the link between labour and the accumulation of capital and unable to handle money (Rooney, 2019, p. 164). However, it could be argued that the extremely low wages that these classes of people have access to are insufficient to meet basic survival needs (Gibson, 2019; Hukula, 2019; Sharp et al., 2015); therefore, they understand the relationship between work and accumulation only too well.

This kind of popular narrative is also used to explain why young men turn to petty and violent crime-they crave goods and lifestyles that are beyond their financial reach and so attempt to gain them by force. While there exist realities of crime and violence in urban settlements (Gewertz \& Errington, this volume), blaming urbanisation ignores the prevalence of rural violence and rests on a national mythology that romanticises village life (Macintyre, 2008, p. 181).

Returning to the editorial in The National (see above), the middle classes are acknowledged as also having been fooled by the fast money schemes' promises of great wealth. However, they are not represented as being gullible or greedy. Rather, they are represented as sophisticated and even discerning, taking the returns of the pyramid schemes and then reinvesting their money elsewhere. This may have been the experience of a tiny fraction of the elite, but this was certainly not a typical outcome. In interviewing dozens of middle-class fast money scheme investors since the quoted editorial was published, I have only met two who made money from the scheme (and one who had his principal returned to him without interest after having thought twice about his investment). Nevertheless, the underlying understanding is that middle-class financial aspirations are legitimate and informed, whereas grassroots aspirations follow a cargo cult mentality that threatens the social order. 
Very often, cargo cult discourse is located within a modernist narrative of cultural development, in which rural villagers are imagined as living traditional lives without access to-or need for-cash. This supposed naivety in relation to money leaves them vulnerable to cargo cult thinking. As my friend Roga, a lecturer at Divine Word University in Madang, explained to me:

It's something that comes out from deep inside our culture. When they see a white man coming, they think, 'Oh yes, here comes some money. How can we get some of that money?' It started after the war with the cargo cults-they wait for the big ship to come, full of money! Now Noah, he's the latest one in Bougainville. And here in Madang we had the Black Jesus—-he was promising all his followers, 'If you join with me, you can have so much money!'

This account provides a typical culturalising explanation that conflates cargo cults with money schemes, such as Noah Musingku's U-Vistract scheme. The account is also national in scope. Noah is in Bougainville, but Madang also has its own contemporary cargo cult, the Black Jesus cult—led by Steven Tari, an infamous cult leader from villages in the Transgogol area outside Madang. Tari claimed to be the son of the 1960s cargo cult leader Yali (Lawrence, 1964) and also the incarnation of the Black Jesus. In 2007, Tari was arrested, charged with murder and rape and subsequently imprisoned. It is not clear whether the so-called Black Jesus actually promised his followers money, but in Roga's account, he has been assimilated into the prevailing cargo cult narrative - a feature of an unchanging Melanesian culture that is ill at ease with modernity and at risk of lapsing into an irrational quest for wealth driven by an untameable desire.

In practice, however, fast money schemes cultivated visions of grassroots national development (Cox, 2011, 2018, pp. 127ff.). Thomas, a Sepik labourer resident in the 'Public Tank' settlement outside Madang (on the way to Sisiak, discussed by Gewertz \& Errington, this volume), described his rational, well-thought-through aspirations in anything but the mad, magical rush expected of the cargo cult mentality:

If this is paid and our rewards are given, with our group we have all these development proposals - we have bridges, schools. On the personal level, we have a good house, water, schools, I think the best schools. The guys with me have these little plans and someone who is in the Public Works Department helped them to type everything up. There must be some contribution to the LLGs [local-level governments], having the same treatment. 
There will be something for everyone. There's no selfishness or greediness. We'll share it with others. Also, the people who say bad things about us, we'll show them they're wrong and share with them too. We have AusAID but we can share our own aid program back to our own communities. There will be some controls-you have to have your own plan for large monies.

Thomas presents himself not only as the grassroots planner and organiser that he is (he has also led delegations to successive Madang Governors requesting better services for the settlements) but also as a responsible developmental citizen. Although he has no qualifications himself, he identifies with an ideal of planning by experts, such as his friend from the Public Works Department. Not only does Thomas demonstrate good moral credentials in his commitment to sharing, but his aspirations are for public goods and services, presented and accounted for properly-rather than irresponsible consumption (Cox \& Macintyre, 2014; Cox, 2014; Barnett-Nagshineh, 2019, p. 232). The reference to AusAID, the (nowdefunct) Australian government aid agency, is a rejection of dependency (another signal of moral worthiness) and foreshadows the argument made below about Papua New Guineans taking development into their own hands.

\section{Global Aspirations and the Place of the Poor}

What, then, are acceptable aspirations for the lower classes? Robert Foster (2008) and Alex Golub (2014) have both proposed accounts of contemporary PNG popular national ideologies that imagine the urban middle class as prospering from modernity, while the grassroots remain in a traditional state. The rural grassroots are conceived of as living in a temporal stasis, in which they maintain old cultural traditions. As Macintyre put it:

The lives, experiences and worldviews of town dwellers, of industrial or office workers, have tended to be viewed through the lens of interactions between urban and rural, in which the authentic or base cultural template of values, aspirations and social relationships is located in the rural village. (2011, p. 92) 
What Gewertz and Errington have called 'incommensurable differences' in class become starkly differentiated in relation to what are considered to be legitimate aspirations. Villagers are expected to be able to provide for themselves through subsistence agriculture, perhaps augmented by some small-scale cash cropping or micro-enterprises so that they might afford a few basic commodities: kerosene and soap, tea or tinned fish (Dundon, 2004; Foster, 2002). They are not expected to fully partake in the benefits of modernity, including the benefits requested by West's Maimafu informant from the NGO: medicine, good water supply and access to consumer goods. Such goods are implicitly restricted-temporally, spatially and morally - to the modern, urban professional class, that understands the proper relationship between labour and consumption and, therefore, possesses a worthy moral disposition that equips them to enjoy these benefits without lapsing into the excesses of a cargo cult mentality.

Middle-class aspirations often embrace a cosmopolitan lifestyle modelled on Australia, the former colonial power, or broader ideas of a prosperous global middle class. These aspirations have multiple sources and are stimulated by images seen on television, such as Australian soap operas; new shopping malls, such as Vision City in Waigani, which has an iconic status within Port Moresby as a modern urban space; new housing schemes that allow professionals to live in gated communities in new residential areas and through international travel for study, workshops, church activities and, increasingly, for tourism. Perhaps most accessibly, aspirations are stimulated through social media; for example, Facebook is now the dominant platform and allows transnational connections to flourish (Barbara, Cox \& Leach, 2015; Foster \& Horst, 2018). Social media use is no longer limited to the middle class; the pull of these global imaginaries extends well beyond PNG's urban elite to many other communities. Those who are faced with the possibility of a mine or other large-scale resource development may imagine their villages turning into cities (Bainton, 2010; Macintyre, 2003: 121; Main, this volume).

The cosmopolitan urban lifestyle is not merely a fantasy. Many middleclass Papua New Guineans enjoy relatively prosperous circumstances that allow them to travel internationally for holidays (typically to Australia, Fiji, Indonesia or Israel, where the pull of Christian pilgrimages to the Holy Land is strong), to eat out regularly or to live in new condominiums. This fortunate group typically occupy higher levels of the business, professional or aid management elite and have grown up in urban centres with educated parents and siblings. Macintyre (2011) has documented 
how these changed circumstances allow contemporary middle-class Melanesian women greater individual freedoms than in any previous generation. Ceridwen Spark (2014) showed that new, more assertive and creative dispositions are flourishing and being valourised in the language of empowerment and personal success among this class of young women in PNG and across the Pacific region (see also Brimacombe, 2016). Although Melanesian cities have been male-dominated spaces since their establishment by colonial powers, women are now negotiating these spaces, often quite independently of male companions or protectors, and following paths of their own career advancement and other projects of personal development (Demian, 2017; Spark, 2011). Urban Pentecostal churches often provide a sympathetic community for modern professionals and mediate some of the moral perils associated with the individualism inherent in global middle-class lifestyle aspirations (Cox \& Macintyre, 2014; Marshall-Fratani, 2001).

However, this description of prosperity and liberation paints far too rosy a picture. Melanesian professional women find working with condescending Australian aid program managers to be both humiliating and infuriating (Spark, 2020). Anxiety, disillusionment and 'downward mobility' are also prevalent. In addition to other scholars, I have previously written of the economic precarity of the PNG middle class (Cox, 2013; Gibson, 2019; Macintyre, 2011; Rooney, 2019; Sharp et al., 2015). The costs of living in Melanesian cities exceed what most wage-earners can sustain; therefore, household budgets are often strained. The obligations of urbanites to their rural kin are perpetually troubling because demands for school fees, medical expenses and funeral or brideprice contributions cannot be ignored indefinitely (Monsell-Davis, 1993). Managing these demands is difficult, but many in the middle class are aware of their own privileges. As Spark (2018) observes:

While the middle class in PNG are maligned for turning their backs on their grass roots counterparts, internationally educated and cosmopolitan women .... are acutely aware that they are products of a context in which some are afforded more opportunities than others. (p. 279)

For the most part, middle-class people do recognise the legitimacy of these needs, even as they try to protect themselves from an impossible deluge of demands. Some are more disparaging and fear that their generosity creates an unhealthy dependency that makes the grassroots unproductive and 
fosters a 'handout mentality' (Foster, 2008, p. 111; Gewertz \& Errington, 1999, p. 49; Martin, 2007). 'Handout mentality' is a variant of 'cargo cult mentality'. Some fear that if they fail to meet expectations, their relatives may punish them with sorcery (Dalsgaard, 2013, p. 292). Therefore, maintaining good relations is important for avoiding this, particularly for those who imagine themselves retiring to a peaceful village life.

Many have reached an understanding with their kinsfolk that realistically acknowledges the limitations of their capacity to meet demand. Peter, a New Irelander in his 50s, who works in Madang as a secondary schoolteacher, provided an example of how these agreements are negotiated:

We tell our folks-we're saving this much and we'll give it to you but when we don't have anything we'll tell you. They're not jealous of our savings because we help them a lot. So, they don't have any bad feelings about what we do. We have our budget and we live by that and we have some savings for requests from our relatives but, if we don't have it, we don't go asking others for it. If we borrow something it must be returned very quickly. I don't like living with debts. In fact, we don't have any debts! We don't make commitments or if we do, we save for it.

Peter exemplifies the rational, financially disciplined, middle-class subject who saves money and spends within his means. In the eyes of the self-help scheme described by Bainton (2011), he would be considered well and truly 'viable'. However, the moral economy of accumulation for Peter is not focused on personal advancement. Rather, it extends to an active role in maintaining good relations with (and redistributing money to) his family back 'home':

What's the point of saving money if you have relatives in need? It's important to us because we understand their situation. Life is home but we only go every two years because we spend a lot of money there-much more than we would in four weeks back here. We admire our people for living the kind of life they live-garden food, fishing, pigs, chickens and when they have the money canned stuff. The cost of goods in Kavieng is more expensive than here but it's even more expensive in the village. We feel we have to contribute to the village economy but the local trade stores are much more expensive. We decide to support them because we see that they really struggle and we want to support the village economy. 
In Peter's case, these enduring family connections mediate the structural divisions of class. Peter maintains contact with his relatives through mobile phone contact, which helps him to manage their demands and expectations, particularly for visits to town. He describes the impact of the mobile phone on these relationships as follows:

It's the answer to the lack of transport and the cost of transport. You can say, 'Don't waste your money on transport, wait'. It's more economical for me to pay for credit on their phones than to house them and feed them when they visit.

Like many urban wage-earners (Dalsgaard, 2013, pp. 292ff.), Peter anticipated retiring to the village. However, he passed away in 2014 and missed the opportunity to enjoy that return.

Peter's case may represent one mode of close and amicable connection between extended families that are stretched between town and village. Certainly, much love exists in these relationships, rather than only burdensome obligations. When, for instance, educated women save their own money to reinvest in the education of their nieces or other children within the extended family (Macintyre, 2011), they are identifying closely with individuals and trying to set them up for social mobility and economic independence or, at least, to do what they can to provide them with this opportunity (see also McDougall, this volume).

At a more elite level, the Business and Professional Women's Club of Port Moresby provides an institutionalised mode of addressing such needs and aspirations. The Club brings successful career women together to fund scholarships for girls whose families do not have the means to support their education. The Club also provides mentoring and networking opportunities that assist its members to negotiate their careers in male-dominated workplaces (Spark \& Lee, 2018). Rasmussen has also documented a Port Moresby-based club of Manusians (the Mbuke Islands People's Association) who gathered together to raise funds for projects back in Manus and even established a 'business arm' for this purpose (Rasmussen, 2015, pp. 143ff.).

Where the Business and Professional Women's Club or the Mbuke Islands People's Association may exemplify the formalised charitable activities of the Port Moresby business community or a distinct provincial or cultural group, there is also a relatively recent parallel trend in which the internal remittance economy is taking a developmentalist turn 
within PNG families. Remittances to close kin are being construed as development projects; professionals send money 'back to the village' for specific 'projects', such as building a water tank or installing solar panels. Others try to set up their rural relatives in small businesses that they hope will allow them to be more financially independent, fulfilling a role as productive labourer-citizens in the national economy. This trend echoes the global turn in development policy towards microenterprise and income generation projects across both not-for-profit and private sector actors alike. In PNG, this includes mining companies that set up small projects for women and other groups not likely to receive royalties directly (Macintyre, 2003).

Sometimes, this business activity is not actually located in the village (the paradigmatic locus of development); rather, it extends to creating markets for products that villagers have grown or made. Others have set up relatives in small kiosks or driving taxis in Port Moresby or other towns. An enterprising Manusian friend of mine has used her free time to set up a stall at a fashionable Port Moresby market (augmented by a Facebook page), where she sells handicrafts made by her relatives on Manus. She enjoys the benefits of a well-paid position, comes from a well-educated family and does not complain of burdensome requests from her relatives. However, she does feel for their disadvantaged circumstances and has begun this business expressly to create income-generating opportunities for the people 'back home'. These new commodity chains are not lacking in interpersonal warmth, nor do I think they turn kin relationships into market transactions. Indeed, much of the evidence from research into commodity chains in Melanesia suggests that commodities gain their mobility through good relationships and friendships (Sharp, 2016, 2019). However, some subtle shifts occur in the distribution of power through these networks of kin.

My previous work has described how middle-class desires to be catalysts for development among their rural kin were exploited by the fast money scheme U-Vistract (Cox, 2018, pp. 141ff.; Cox \& Macintyre, 2014). In my analysis of these dynamics, I have argued that, as middle-class Papua New Guineans begin to see their relatives through the lens of the development project, they adopt a 'sentimental cosmopolitanism' akin to that fostered by international NGOs in their fundraising (Black, 2009). Black studied KIVA, a large microfinance NGO that connects donors in the Global North with recipients in the Global South, through the exchange of stories over the internet. The success of KIVA depends 
on donors feeling not only that they have done some good by helping someone in need, but also that they have made an emotional connection with the recipients. Middle-class Papua New Guineans are adopting similar dispositions as they begin to see their rural kin as subjects who must be mobilised for development. As Thomas, the mercurial Sepik from Public Tank settlement put it, imagining himself in the position of a wealthy patron enriched by a money scheme, 'we can share our own aid program back to our own communities'. These dispositions contain disparities of power that become a form of 'Christian patronage', in which well-intentioned Christian professionals position themselves as personalised disbursers of development in ways that mirror Melanesian systems of political patronage (Cox, 2018, p. 152; cf. Main, this volume). Patrons are the more powerful parties in patron-client relationships; they are able to determine the kinds of development projects that they are willing to fund. Moreover, the role of the state as a provider of routine expert services is replaced by the patron's petty disbursements and projects (Cox, 2009).

\section{Situating Social Mobility: The Village Cargo Cult Mentality versus Middle-Class Vocation}

If the rural poor are subaltern subjects that require developing, this constitutes a constraint on other aspirations they may have. Moralistic narratives of blame, such as cargo cult discourse, play a powerful role in legitimating the place of patrons and shaping the kinds of desires to which the grassroots may properly aspire. In my own fieldwork, I have encountered almost identical scenarios to the one documented by West, in which middle-class development program staff lambaste villagers for having a 'cargo cult mentality'. Here, I focus on the account of a middleclass development NGO worker, rather than on the villagers whom he was trying to influence. My informant, Andrew, was a well-educated Sepik man in his late twenties who had been working for an environmental NGO in Madang province on efforts to reduce illegal logging through small-scale 'eco-forestry', using portable sawmills and trying to improve market access for locally harvested timber. 
At the time I interviewed him in 2009, he held a new position at Divine Word University. Despite the judgemental attitude that I document below, I liked him and was fortunate enough to catch up with him a few months after the completion of my fieldwork, when he attended a conference in Melbourne. In Madang, he had been describing the activities of Pentecostal pastors as 'cargo cult', another common application of the term (Cox, 2018, p. 117). When I pressed him on exactly what he meant by this; he responded as follows:

I'd like to talk about two examples from my work with an NGO from the Sogoram area in Madang. It's in the TransGogol LLG and the other is in the Usina-Bundi LLG. People are scattered around with limited access to resources. The Japan and New Guinea Timber Company was active in that area, so they have high expectations because they had an easy start with royalties. They don't want to work but expect that NGOs will bring money. I have to explain to them that we are not bringing bulldozers and that kind of equipment.

It's a cargo cult mentality-they want access to resources to change their lifestyles but they don't want to work for it. It was hard working with them. When we were doing an activity in the village people give excuses - they say they're working on their gardens or have other commitments. This is something the timber company has done. It promotes laziness among people-a cargo cult mentality. They have land and they can till the soil but they don't want to, they just sit around.

In Andrew's (middle-class) mind, the people expect something for nothing. However, in this case, their (to him unrealistic) expectations are not inherent, nor are they provoked by the promises made by his NGO (as in West's example) or their politicians. Rather, their lack of interest in bettering themselves is the result of being spoiled by logging company largesse. Like many town dwellers, mining companies and development agencies, Andrew imagines rural life as paradisaical, where life is timeless and work in subsistence horticulture is easy. For him and many others, the work that people do in their gardens could not be as important or rewarding as participation in a development program.

For Andrew, the 'noncompliance' of the villagers with his project was unacceptable and needed to be dealt with strictly_by 'scolding' the people. Scolding is not uncommon in PNG, although the term has fallen from use in contemporary English elsewhere, and seems to reflect 
a mode of exercising authority that derives from the colonial period. Alice Street, in her ethnography of Modillon Hospital in Madang, has observed nurses who hector patients and demand that they demonstrate their moral worthiness (2014). Stephanie Lusby has documented the violent practices of the PNG security industry, in which security guards are beaten into submission by their overseers (2017, pp. 30ff.). This violence is understood as reforming them into good citizens. In Andrew's case, despite his age, a similar disciplining role for him as a development worker overturned the traditional intergenerational hierarchy. This suggests that class is a more important form of privilege than age:

As a young man it's difficult but I have to scold at old people when they are stubborn and don't want to do the activities for their own benefit.

Andrew admitted that this was not very effective; therefore, I asked him if he changed his approach when he realised it was not working. He answered as follows:

Sometimes I try. People are people. It's too much to deal with human beings like they're inferior objects like pigs or dogs. So to scold someone is treating them like a dog. I always use that approach. I talk hard at them and then later I explain why I had to speak like that. At times I tell them I'm just wasting my time with such people who have such an attitude to development. 'You're lazy', I used to tell them, 'you're lazy'. They're remote, hungry for development. The government is not likely to do that for them, so they need NGOs but they are unwilling to work hard for those changes.

I asked him more about scolding: 'but this approach of scolding them didn't work?' He said:

I'd change my approach. When we go to the villages, normally we buy some food items. But people come for rice and biscuits, not to work, so I'd do away with manufactured items. Because we are there for them, it's their obligation to provide stuff. If they don't give it, we can buy from them.

Andrew's attempts to soften his approach seemed to run into conflict with his own impatience and his ideological investment in the victimblaming cargo discourse. I pressed him further on whether his scolding was effective, and he revealed how ingrained the discourse of self-blame is in developmental interactions in PNG: 
It's effective because some of them said I have to talk harder in order to have the mandate and have authority over them. This contradicts my own values and opinion. I only scold the dogs.

This extraordinary disparagement of noncompliant villagers is remarkable; not only does Andrew judge them as lazy, but this judgement also removes some of their humanity, meaning that they must be treated like dogs. This is an almost exact re-enactment of colonial racist authority that, historically, has driven the cargo cult trope (Buck, 1988; Lindstrom, 1993 ) and is remembered by many as the origin of inequality (Rousseau, 2015). Andrew justified his scolding as a departure from normal manners and ethics that was required by the context. Some villagers who supported the project urged him on, supporting his sense that cargo cult villagers require much less respectful treatment than he would usually extend to normal, middle-class people like himself. The acceptance of scolding by some villagers implies an acceptance or internalisation of the middle-class moral valuations of rural life and subsistence work. This is an example of the developmental paternalism documented by West, in which villagers are to be scolded like naughty children. The village context was a revelation to Andrew:

I didn't know about cargo cult until I was here and then I saw the pattern of their behaviour. I may have heard it as a child and have heard of examples of some activities when people want free stuff. But I wasn't able to know what cargo cult is until I've seen cargo cult in the village. Understanding cargo cult came from being confronted with such attitudes working with the people, in the village but not just village groups but other organisations.

The horror of the inertia of villagers, whom he saw as subject to a cargo cult mentality, was confronting for Andrew. However, for him, the lack of temporal momentum shown by these noncompliant and backward villagers stood in contrast to his own social and temporal mobility:

I used to tell them, 'I'm a young man. I want to go for further studies. I can't waste my time with you, who don't want to see development. I'd rather spend time with those who are willing to work.' This experience, on the other hand, was a good one. It improves myself as a community development worker. It helps to change strategies to work with communities. One strategy is not acceptable. It has to be flexibility. I have to change my approach. People have to work. 
Placed in a difficult context and confronted by inequality, Andrew retreated into a middle-class narrative of his own 'moral career' (Chu, 2010). Here, we may observe a different side of these 'developmental' interactions than was visible to West in her village fieldwork or to Gewertz and Errington in Wewak. For Andrew, the unfruitful interaction with a noncompliant village was reinterpreted as an experience that he could learn from, and that would form part of his portfolio of moral and professional progression.

Academic discussions of careers in PNG have largely focused on the dilemmas of professional women (Macintyre, 1998, 2011; Spark, 2011, 2020); or accounts of young men without a clear 'moral career' (e.g. Gewertz \& Errington; McDougall, this volume). But the place of career progression and vocation as a constitutive element of class identity has largely been overlooked. Through his (albeit challenging) work for the environmental NGO, Andrew accumulated not only financial capital from his wages, but also professional cultural capital that would advance his career. He even demonstrated his credentials along this career trajectory via using modern managerialist buzzwords, such as 'strategy' and 'flexibility'.

However, this flexibility was not entirely open-ended. Although Andrew may have needed to adapt his strategies, the goal remained the same-'[grassroots] people have to work'. The work ethic of the poor is foregrounded as the primary obstacle to development, just as in the microfinance program studied by Gewertz and Errington and in the selfhelp course documented by Bainton. Like the would-be entrepreneurs envisaged by these two programs, Andrew demonstrated the drive to 'get ahead' and advance himself, though this was through study and professional work rather than the pursuit of business.

This narrative of middle-class career progression is nested within a broader nation-making narrative of productive (professional, urban) citizens contributing to the collective project of national development. The nation itself is seen as suffering from a pathological dependency on aid and foreign multinational companies; therefore, it must become economically independent. PNG Prime Minister James Marape has made ambitious public statements that draw on this sentiment, stating that he intends to make PNG 'the richest black nation in the world' (Graue, 2019) and pledging that PNG will not be dependent on Australia in 10 years' time (Lyons \& Davidson, 2019). U-Vistract articulated a similar vision, 
boasting that PNG would become an aid donor to smaller countries in the region (Cox, 2018, p. 197). Perhaps, Marape's muscular economic nationalism exhibits echoes of the global populist zeitgeist, but it also represents a response to perceptions of the failure of the O'Neill government (in which Marape served as Treasurer) to put the benefits of the resources boom towards public services that might improve the wellbeing of the majority of the population.

\section{Conclusion: Inequality of Aspiration}

PNG's middle-class may struggle with the cost of living, but they experience this as a failure of the system to provide the benefits that they feel they should enjoy, given their education, work ethic and overall position in society. As individuals, many imagine themselves called to a particular career path that God has planned for them and hope to work their way into promotions and social mobility (Macintyre, 2011). The religious element of this vocation or moral career has fallen from most Western accounts of career progression, but it remains fundamental to imaginings of the life course in PNG. Perhaps the most distinctively PNG feature of this 'vocation' is the way that it is nested within a narrative of national development. As the nation's skilled professionals advance through their careers, they fulfil part of the developmental destiny of PNG (Cox, 2018).

Looking down the ladder of class, the grassroots cannot access the same career mobility. Rather, they are regarded as stationary custodians of the nation's traditional cultural heritage, grounded in subsistence agriculture. Urban grassroots are usually regarded as dangerously out of place, particularly in the case of women and young men (Lepani, 2008; Macintyre, 2008). Their aspirations are severely constrained and, when articulated to middle-class actors, typically met with condescension or explicit moral condemnation.

Nevertheless, even as they condemn the handout mentality, middleclass Melanesians still extend a hand to their less fortunate kin. I have argued that this increasingly takes the form of 'projects' and that new forms of inequality are taking shape as a result of this developmentalist language. Middle-class 'donors' (this is not a term I have heard used in PNG) to rural kinsfolk are occupying positions of patronage that are analogous to Melanesian political clientelism, based on the disbursement of favours. Disturbingly, aspirations for more equitable development in 
the form of basic health and education services give way to patronage that systematically neglects public goods and cultivates a dysfunctional governmentality of low expectations, where grassroots no longer have confidence that they are entitled to the rights of citizens.

\section{References}

Akin, D. (2013). Colonialism, Maasina rule and the origins of Malaitan kastom. Honolulu, HI: University of Hawaii Press.

Bainton, N. (2008). The genesis and the escalation of desire and antipathy in the Lihir Islands, Papua New Guinea. The Journal of Pacific History, 43(3), 289-312.

Bainton, N. (2010). The Libir destiny: Cultural responses to mining in Melanesia. Canberra, ACT: ANU E Press. doi.org/10.22459/LD.10.2010

Bainton, N. (2011). 'Are you viable?' Personal avarice, collective antagonism and grassroots development in Papua New Guinea. In M. Patterson \& M. Macintyre (Eds), Managing modernity in the Western Pacific (pp. 231-259). St Lucia, Qld: University of Queensland Press.

Bainton, N. \& Cox, J. (2009). Parallel states, parallel economies: Legitimacy and prosperity in Papua New Guinea (SSGM Discussion Paper 2009/5). Canberra, ACT: The Australian National University.

Barbara, J., Cox, J. \& Leach, M. (2015). The emergent middle classes in TimorLeste and Melanesia: Conceptual issues and developmental significance (SSGM Discussion Paper 2015/4). Canberra, ACT: The Australian National University.

Barnett-Nagshineh, O. (2019). Shame and care: Masculinities in the Goroka marketplace. Oceania, 89(2), 220-236.

Black, S. (2009). Microloans and micronarratives: Sentiment for a small world. Public Culture, 21(2), 269-292.

Brimacombe, T. (2016). Trending trousers: Debating kastom, clothing and gender in the Vanuatu mediascape. The Asia Pacific Journal of Anthropology, $17(1), 17-33$.

Buck, P. (1988). Cargo-cult discourse: Myth and the rationalisation of labor relations in Papua New Guinea. Dialectical Anthropology, 13, 157-171. 
Burridge, K. (1960). Mambu: A Melanesian millennium. Princeton, NJ: Princeton University Press.

Cahn, P. (2006). Building down and dreaming up: Finding faith in a Mexican multilevel marketer. American Ethnologist, 33(1), 126-142.

Cahn, P. (2008). Consuming class: Multilevel marketers in neoliberal Mexico. Cultural Anthropology, 23(3), 429-452.

Chu, J. (2010). Cosmologies of credit: Transnational mobility and the politics of destination in China. Durham, NC: Duke University Press.

Cox, J. (2009). Active citizenship or passive clientelism: Accountability and development in Solomon Islands. Development in Practice, 19(8), 964-80.

Cox, J. (2011). Prosperity, nation and consumption: Fast money schemes in Papua New Guinea. In M. Patterson \& M. Macintyre (Eds), Managing modernity in the Western Pacific (pp. 172-200). St Lucia, Qld: University of Queensland Press.

Cox, J. (2013). The magic of money and the magic of the state: Fast money schemes in Papua New Guinea. Oceania, 83(3), 175-191.

Cox, J. (2014). Fast money schemes are risky business: Gamblers and investors in a Papua New Guinean ponzi scheme. Oceania, 84(3), 289-305.

Cox, J. (2015). Israeli technicians and the post-colonial racial triangle in Papua New Guinea. Oceania, 85(3), 342-358.

Cox, J. (2016). Value and the art of deception: Public morality in a Papua New Guinean ponzi scheme. In L. Angosto-Ferrandez \& G. Presterudstuen (Eds), Anthropologies of value: Cultures of accumulation across the global North and South (pp. 51-74). London, England: Pluto Press.

Cox, J. (2018). Fast money schemes: Hope and deception in Papua New Guinea. Bloomington, IN: Indiana University Press.

Cox, J. (2019). Money schemes in contemporary Melanesia. In E. Hirsch \& W. Rollason (Eds), The Melanesian world (pp. 180-193). Routledge Worlds Series. London, England: Routledge.

Cox, J. \& Macintyre, M. (2014). Christian marriage, money scams and Melanesian social imaginaries. Oceania, 84(2), 138-157. 
Cox, J. \& Phillips, G. (2015). Sorcery, Christianity and the decline of medical services in Melanesia. In M. Forsyth \& R. Eves (Eds), Talking it through: Responses to sorcery and witchcraft beliefs and practices in Melanesia (pp. 37-54). Canberra, ACT: ANU Press. doi.org/10.22459/TIT.05.2015

Dalsgaard, S. (2013). The politics of remittance and the role of returning migrants: Localising capitalism in Manus Province, Papua New Guinea. Research in Economic Anthropology, 33, 277-302.

Demian, M. (2017). Making women in the city: Notes from a Port Moresby boarding house. Signs: Journal of Women in Culture and Society, 42(2), 403-425.

Dundon, A. (2004). Tea and tinned fish: Christianity, consumption and the nation in Papua New Guinea. Oceania, 75(2), 73-88.

Foster, R. (2002). Materialising the nation: Commodities, consumption and media in Papua New Guinea. Bloomington, IN: Indiana University Press.

Foster, R. (2008). Coca-globalisation: Following soft drinks from New York to New Guinea. New York, NY: Palgrave Macmillan.

Foster, R. \& Horst, H. (Eds). (2018). The moral economy of mobile phones: Pacific Islands perspectives. Canberra, ACT: ANU Press. doi.org/10.22459/MEMP. 05.2018

Gewertz, D. \& Errington, F. (1998). Sleights of hand and the construction of desire in a Papua New Guinea modernity. The Contemporary Pacific, 10(2), 345-368.

Gewertz, D. \& Errington, F. (1999). Emerging class in Papua New Guinea: The telling of difference. Cambridge, England: Cambridge University Press.

Gibson, L. (2019). Class, labour and consumption in urban Melanesia. In E. Hirsch \& W. Rollason (Eds), The Melanesian world (pp. 164-179). London, England: Routledge.

Golub, A. (2014). Leviathans at the gold mine: Creating indigenous and corporate actors in Papua New Guinea. Durham, NC: Duke University Press.

Graue, C. (2019, 30 May). James Marape elected as PNG's new Prime Minister. Australian Broadcasting Corporation. Retrieved from www.abc.net. $\mathrm{au} /$ radio-australia/programs/pacificbeat/james-marape-elected-as-pngs-newprime-minister/11165242

Gregory, C. \& Altman, J. (2018). Preface. In C. Gregory \& J. Altman (Eds), The quest for the good life in precarious times: Ethnographic perspectives on the domestic moral economy (pp. xvii-xix). Canberra, ACT: ANU Press. doi.org/ 10.22459/QGLPT.03.2018 
Hukula, F. (2019). Morality and a Mosbi market. Oceania, 89(2), 168-181.

Karim, L. (2011). Microfinance and its discontents: Women and debt in Bangladesh. Minneapolis, MN: University of Minnesota Press.

Krige, D. (2012). Fields of dreams, fields of schemes: Ponzi finance and multilevel marketing in South Africa. Africa: The Journal of the International African Institute, 82(1), 69-92.

Lattas, A. (2007). Cargo cults and the politics of alterity: A review article. Anthropological Forum, 17(2), 149-161.

Lawrence, P. (1964). Road belong cargo: A study of the cargo movement in the southern Madang District, New Guinea. Melbourne, Vic.: Melbourne University Press.

Lepani, K. (2008). Mobility, violence and the gendering of HIV in Papua New Guinea. The Australian Journal of Anthropology, 19(2), 150-164.

Lindstrom, L. (1993). Cargo cult: Strange stories of desire from Melanesia and beyond. Honolulu, HI: University of Hawai'i Press.

Lusby, S. (2017). Securitisation, development and the invisibility of gender. In M. Macintyre \& C. Spark (Eds), Transformations of gender in Melanesia (pp. 23-43). Canberra, ACT: ANU Press. doi.org/10.22459/TGM.02.2017

Lyons, K. \& Davidson, H. (2019, 26 July). Papua New Guinea will not be dependent on Australia in 10 years, new PM says. The Guardian. Retrieved from www.theguardian.com/world/2019/jul/26/papua-new-guinea-will-notbe-dependent-on-australia-in-10-years-new-pm-says

Macintyre, M. (1998). The persistence of inequality: Women in Papua New Guinea since independence. In L. Zimmer-Tamakoshi (Ed.), Modern Papua New Guinea (pp. 211-31). Kirksville, MO: Thomas Jefferson Press.

Macintyre, M. (2003). Petztorme women: Responding to change in Lihir, Papua New Guinea. Oceania, 74(1/2), 120-133.

Macintyre, M. (2008). Police and thieves, gunmen and drunks: Problems with men and problems with society in Papua New Guinea. The Australian Journal of Anthropology, 19(2), 179-193.

Macintyre, M. (2011). Money changes everything: Papua New Guinean women in the modern economy. In M. Patterson \& M. Macintyre (Eds), Managing modernity in the Western Pacific (pp. 90-120). St Lucia, Qld: University of Queensland Press. 
Macintyre, M. (2013). Instant wealth: Visions of the future on Lihir, New Ireland, Papua New Guinea. In M. Tabani \& M. Abong (Eds), Kago, kastom and kalja: The study of indigenous movements in Melanesia today (pp. 123-146). Marseilles, France: Pacific-CREDO Publications.

Marshall-Fratani, R. (2001). Mediating the global and local in Nigerian Pentecostalism. In A. Corten \& R. Marshall-Fratani (Eds), Between Babel and Pentecost: Transnational Pentecostalism in Africa and Latin America (pp. 80-105). Bloomington, IN: Indiana University Press.

Martin, K. (2007). Your own buai you must buy: The ideology of possessive individualism in Papua New Guinea. Anthropological Forum, 17(3), 285-298.

Martin, K. (2013). The death of the big men and the rise of the big shots: Custom and conflict in East New Britain. New York, NY: Berghahn Books.

Modern Shylocks [Editorial]. (2005, 10 November). The National.

Monsell-Davis, M. (1993). Urban exchange: Safety-net or disincentive? Canberra Anthropology, 16(2), 45-66.

Okole, H. (2003). Enhancing nation building through the provincial government system in Papua New Guinea. In D. Kavanamur, C. Yala \& Q. Clements (Eds), Building a nation in PNG: Views of the post-independence generation (pp. 51-67). Canberra, ACT: Pandanus Books.

Rasmussen, A. (2015). In the absence of the gift: New forms of value and personhood in a Papua New Guinea community. London, England: Berghahn.

Rooney, M. N. (2019). Sharing what can be sold: Women haus maket vendors in Port Moresby's settlements. Oceania, 89(2), 154-167.

Rousseau, B. (2015). Finding the diamond: Prosperity, secrecy and labour in Vanuatu. Oceania, 85(1), 24-37.

Schiffhauer, L. (2018). Dangerous speculation: The appeal of pyramid schemes in rural Siberia. Focaal: Journal of Global and Historical Anthropology, 81, 58-71.

Schram, R. (2015). Notes on the sociology of Wantoks in Papua New Guinea. Anthropological Forum, 25(1), 3-20.

Schuster, C. (2015). Social collateral: Women and microfinance in Paraguay's smuggling economy. Oakland, CA: University of California Press.

Sharp, T. (2016). Trade's value: Relational transactions in the Papua New Guinea betel nut trade. Oceania, 86(1), 75-91. 
Sharp, T. (2019). Haggling highlanders: Marketplaces, middlemen and moral economy in the Papua New Guinean betel nut trade. Oceania, 89(2), 182-204.

Sharp, T., Cox, J. Spark, C., Lusby, S. \& Rooney, M. (2015). The formal, the informal and the precarious: Making a living in urban Papua New Guinea (SSGM Discussion Paper 2015/2). Canberra, ACT: The Australian National University.

Smith, R. (2018). Changing standards of living: The paradoxes of building a good life in rural Vanuatu. In C. Gregory \& J. Altman (Eds), The Quest for the good life in precarious times: Ethnographic perspectives on the domestic moral economy (pp. 33-55). Canberra, ACT: ANU Press. doi.org/10.22459/QGLPT.03.2018

Spark, C. (2011). Gender trouble in town: Educated women eluding male domination, gender violence and marriage in PNG. The Asia Pacific Journal of Anthropology, 12(2), 164-179.

Spark, C. (2014). An oceanic revolution? Stella and the construction of new femininities in Papua New Guinea and the Pacific. The Australian Journal of Anthropology, 25(1), 54-72.

Spark, C. (2018). Hybridity in Port Moresby: Gender, class and a 'tiny bit of feminism' in postcolonial Papua New Guinea. In J. Wallis, L. Kent, M. Forsyth, S. Dinnen \& S. Bose (Eds), Hybridity on the ground in peacebuilding and development: Critical conversations (pp. 271-285). Canberra, ACT: ANU Press. doi.org/10.22459/HGPD.03.2018

Spark, C. (2020). 'Two different worlds': Papua New Guinean women working in development in Port Moresby. Asia Pacific Viewpoint. Advance online publication. doi.org/10.1111/apv.12271

Spark, C. \& Lee, J. (2018). Successful women's coalitions in Papua New Guinea and Malaysia: Feminism, friendships and social change (Developmental Leadership Program Research Paper 50). Birmingham, England: University of Birmingham.

Street, A. (2014). Biomedicine in an unstable place: Infrastructure and personhood in a Papua New Guinean hospital. Durham, NC: Duke University Press.

Suti, E., Hoatson, L. Tafunai, A. \& Cox, J. (2020). Leadership, linkages and locality: The Simbo for Change project. Asia Pacific Viewpoint. Advance online publication. doi.org/10.1111/apv.12260

Verdery, K. (1995). Faith, hope and caritas in the Land of the Pyramids: Romania, 1990 to 1994. Comparative Studies in Society and History, 37(4), 625-699.

West, P. (2001). Environmental NGOs and the nature of ethnographic inquiry. Social Analysis, 45(2), 55-77. 
West, P. (2006). Conservation is our government now. The politics of ecology in Papua New Guinea. Durham, NC: Duke University Press.

West, P. (2016). Dispossession and the environment: Rhetoric and inequality. New York, NY: Columbia University Press.

Wood, T. (2019). The clientelism trap in Solomon Islands and Papua New Guinea and its impact on aid policy. Asia Pacific Policy Studies, 5, 481-494.

Zimmer-Tamakoshi, L. (1997). The last big man: Development and men's discontents in the Papua New Guinea Highlands. Oceania, 68(2), 107-122. 
This text is taken from Unequal Lives: Gender, Race and Class in the Western Pacific, edited by Nicholas A. Bainton, Debra McDougall, Kalissa Alexeyeff and John Cox, published 2021 by ANU Press, The Australian National University, Canberra, Australia.

doi.org/10.22459/UE.2020.09 